УДК 331.5

Чорна Неля,

доктор економічних наук, професор,

Тернопільський національний економічний університет, кафедра обліку та економіко-правового забезпечення агропромислового бізнесу, м. Тернопіль, ORCID ID 0000-0001-9719-6043, e-mail: neolla@ukr.net

Чорний Роман, доктор економічних наук, професор,

Тернопільський національний економічний університет, Нововолинський навчально-науковий інститут економіки і менеджменту, директор, м. Нововолинськ; ORCID ID 0000-0001-8614-9495 e-mail: roman.nv79@gmail.com

https://doi.org/10.29038/2411-4014-2020-01-64-73

\title{
РИНОК ПРАЦІ УКРАЇНИ: СУЧАСНІ ВИКЛИКИ
}

У статті розкрито сутність ринку праці та його основних функцій. Досліджено сучасний стан ринку праці України, виявлено основні проблеми та запропоновано шляхи їх вирішення. Узагальнено причини недосконалої взаємодії ринків праці та освіти, визначено напрямки подолання освітньо-кваліфікаційних дисбалансів. Ідентифіковано ймовірні вигоди та ризики від впливу глобалізації, економіки знань, розвитку інформаційного суспільства на рівень зайнятості населення та безробіття. Обгрунтовано необхідність державного регулювання ринку праці.

Ключові слова: ринок праці, ринок освіти, зайнятість, безробіття, попит, пропозиція, робоча сила, державне регулювання

Чорна Неля, доктор экономических наук, профессор,

Тернопольский национальный экономический университет, кафедра учета и экономико-правового обеспечения агропромышленного бизнеса, г. Тернополь

Чорный Роман, доктор экономических наук, профессор, Тернопольский национальный экономический университет, Нововолынский учебно-научный институт экономики и менеджмента

г. Нововолынск

\section{РЫНОК ТРУДА УКРАИНЫ: СОВРЕМЕННЫЕ ВЫЗОВЫ}

В статье раскрыта сущность рынка труда и его основных функций. Исследовано современное состояние рынка труда Украины, выявлены основные проблемы и предложены пути их решения. Обобщены причины несовершенного взаимодействия рынков труда и образования, определены направления преодоления образовательно-квалификационных дисбалансов. Идентифицированы вероятные выгоды и риски от воздействия глобализации, экономики знаний, развития информационного общества на уровень занятости населения и безработицы. Обоснована необходимость государственного регулирования рынка труда.

Ключевые слова: рынок труда, рынок образования, занятость, безработица, спрос, предложение, рабочая сила, государственное регулирование.

Chorna Nelia,

Doctor of Economics, Professor,

Ternopil National Economic University,

Department of accountanceand economical-law agricultural business provision,

Ternopil 


\section{Chornyi Roman, \\ Doctor of Economics, Professor, \\ Ternopil National Economic University, \\ Novovolynsk Educational-Scientific Institute of Economics and Management, \\ Novovolynsk}

\section{THE LABOUR MARKET IN UKRAINE: CURRENT CHALLENGES}

The effective functioning of the labour market in Ukraine depends, first of all, on the social and economic situation in the country, structural changes in the wourld and national economies are influencing. Globalization, increased competition, development of knowledge economy and information technologies, restructuring of the economy, accelerated economic growth, scientific and technological progress, informatization of society and state regulation have significant impact on the labour market. Long-term imperfection in the interaction between the labour market and the educational market has had a negative effect on both of them, causing the discrepancy between qualification standards and the requirements of the national economy, worsening the quality of staff training and aggravating the disbalance between labour supply and labour demand. This led to a decrease in labour productivity and competitiveness of domestic enterprises, the existence of part-time and unreported employment, the increase of structural and technological unemployment and the inability to provide innovative economic development. Structural changes in the world and national economies influence the formation of aggregate demand in the labour market for qualified specialists who have high level of intellectual potential and will be able to combine several professions. To overcome educational and qualification disbalance between the educational and labour markets, it is necessary to update educational standards and curricula, to apply new teaching methods and training techniques, to improve the mechanism of interaction between both markets. The employees who have unique competencies and are capable of creating innovative technologies and solutions will be in advantageous positions. Scientific and technological progress causes mass automation, robotization, computerization, digitization and, consequently, changes the employment structure significantly, thus posing serious challenges for the labour and educational markets. In a competitive environment, higher and vocational education should be flexible and focus on the future needs of the economy. State regulation of the labour market is an important area of development of the national economy and a necessary process, since it directly affects the expansion of employment opportunities, improving the welfare and living standards of the population. In the market economy environment the labour market should: provide the working population with the income which meets their social and economic needs; reduce social inequality in society and ensure social and economic stability; make the most of the country's labour potential.

Keywords: labour market, educational market, employment, unemployment, demand, supply, labour, state regulation.

Постановка проблеми. В сучасних умовах економічного розвитку України все більшої актуальності набувають проблеми зайнятості населення, запобігання масового безробіття та ефективного функціонування ринку праці. Це, в першу чергу, залежить від соціально-економічного стану в країні, структурних змін та інноваційно-інвестиційного розвитку підприємств. Окрім того, відносини, що виникають на ринку праці, потребують особливої уваги з боку держави. Тому дослідження процесів, що відбуваються на ринку праці України, напрямів його ефективного функціонування в умовах глобалізації та розвитку інформаційного суспільства, $\epsilon$ досить актуальними.

Аналіз останніх досліджень і публікацій. Проблематику функціонування ринку праці України досліджували такі вчені, як: О. Брінцева [1], О. Грішнова [3], Л. Ільїч [7], Е. Лібанова [11, 12], А. Колот [2, 8], Б. Косович [10] та ін. В науковій літературі мають місце дискусійні питання щодо перспектив розвитку національного ринку праці. Сьогодні відкритим залишається питання дослідження даного ринку в умовах глобалізації, економіки знань та нових викликів інформаційного суспільства.

Постановка завдання. Метою статті є дослідження ринку праці України в сучасних умовах, причин негативного впливу на ефективність його функціонування та пошук шляхів стабілізації вітчизняного ринку праці.

Виклад основного матеріалу дослідження. Ринок праці - це система суспільних відносин, пов’язаних $з$ купівлею і продажем трудових послуг працівників. У класичному розумінні ринок праці - це сфера формування попиту і пропозиції на робочу силу. Він охоплює всі категорії працездатного 
населення, яке готове працювати за наймом або в режимі самозайнятості. Ринок праці $є$ механізмом розподілу трудових ресурсів за галузями народного господарства 3 урахуванням професійної підготовки та кваліфікації працівників.

Основними функціями сучасного ринку праці є такі:

- суспільного поділу праці - розмежування роботодавців і найманих працівників за професіями, спеціальностями, галузями, регіонами;

- інформаційна - надання інформації щодо умов найму, рівня заробітної плати, вимог до якості робочої сили;

- посередницька - встановлює зв'язок між роботодавцями та найманими працівниками для задоволення взаємних інтересів та потреб щодо вигідних умов купівлі-продажу товару «робоча сила»;

- ціноутворююча - встановлює рівновагу між попитом і пропозицією робочої сили; під впливом дії закону вартості відбувається визначення витрат праці на відтворення робочої сили;

- регулююча - впливає на формування пропорцій суспільного виробництва, розвиток регіонів, сприяючи переміщенню робочої сили з одних регіонів в інші;

- стимулююча - ринок вимагає якісної робочої сили, стимулюючи найманих працівників поліпшувати свій професійний рівень знань та вмінь, кваліфікованість, компетентність.

В умовах ринкової економіки на ринку праці повинно мати місце:

- забезпечення працюючого населення доходами, що дає можливість задовольняти їх соціальноекономічні потреби;

- зменшення соціальної нерівності в суспільстві та забезпечення соціально-економічної стабільності;

- максимально ефективне використання трудового потенціалу країни.

Суттєвий вплив на розвиток національного та світового ринків праці мають: глобалізація; посилення конкуренції; розвиток економіки знань та інформаційних технологій; структурна перебудова економіки; прискорене економічне зростання; науково-технічний прогрес; інформатизація суспільства; державне регулювання.

Сучасний ринок праці України характеризується дисбалансом між попитом та пропозицією робочої сили, який відображається у професійно-кваліфікаційній невідповідності. Це призводить до підвищення структурного безробіття, що негативно впливає на ефективність функціонування економіки, зниження виробництва товарів та послуг, скорочення ВВП. Для нашої держави також актуальними $є$ внутрішні чинники соціально-економічної нестабільності, пов'язані зі зниженням рівня життя та зайнятості, територіальними диспропорціями між попитом та пропозицією на ринку праці, загостренням ситуації на локальних ринках праці.

Конвенція Міжнародної організації праці про основні цілі та норми соціальної політики № 117 проголошує, що будь-яка політика має спрямовуватися насамперед на досягнення добробуту й розвитку населення (ст. 1). Підвищення життєвого рівня населення розглядається як основна мета планування економічного розвитку (ст.2), стрижневим елементом якого $є$ забезпечення повної та продуктивної зайнятості [9].

На жаль, з часу незалежності України національна економіка не розвивалася на основі інноваційних технологій та економіки знань, що вплинуло на розвиток неефективних виробництв $i$, відповідно, малопродуктивних робочих місць. Нормативно-правові та інституційні обмеження в соціально-трудовій сфері не сприяють забезпеченню гнучкості робочого часу та поширенню нестандартних форм зайнятості в офіційній економіці.

Відбуваються багатовекторні й широкомасштабні зміни на ринку праці, які, однак, далеко не завжди відповідають інтересам найманих працівників. Так, набуває небачених раніше масштабів застосування нестандартних форм зайнятості та режимів робочого часу й атипових трудових договорів. Поширення зазначених форм зайнятості та трудових договорів чимраз частіше стає наслідком як реальних змін у структурі виробництва й організаційно-економічних особливостях його функціонування, так і послаблення співвідношення сил роботодавців i найманих працівників унаслідок слабкості (неадекватності) національного законодавства у сфері праці та зниження ролі соціального діалогу. Трудове законодавство має тенденцію до лібералізації, а колективно-договірне регулювання не охоплює всього різноманіття форм зайнятості, які є реальністю сьогодення [8, с. 12]. 
Кількість зайнятого населення у віці 15 - 70 років за січень-вересень 2019 р. становила 16628 тис осіб, а рівень зайнятості - 58,3\%. За досліджуваний період безробітне населення склало 1462 тис осіб, рівень безробіття $-8,1 \%$. Насправді рівень безробіття занижений через міграцію працездатного населення за кордон.

Державна служба зайнятості в Україні повідомила про 59018 вакансій станом на 1 січня 2020 року, що на 1\% більше, ніж на відповідну дату 2019 року. В цілому за 2019 рік було 1153326 вакансій. За видами економічної діяльності найбільше вакансій пропонувалося: на підприємствах переробної промисловості - 17,9\%, в оптовій та роздрібній торгівлі - $15,7 \%$, у сільському, лісовому та рибному господарстві - $14 \%$.

Найбільший попит на вітчизняному ринку праці спостерігається на робітників з обслуговування, експлуатації устаткування, представників найпростіших професій, працівників сфери торгівлі та послуг, кваліфікованих робітників з інструментом (табл. 1).

Таблиия 1

Кількість вакансійзапрофесійними групами, заресстрованих в державній службі зайнятості

\begin{tabular}{|c|c|c|c|c|c|c|}
\hline & 2018 p. & 2019 p. & $\begin{array}{l}\text { Темпи } \\
\text { зроста- } \\
\text { ння (зни- } \\
\text { ження) }\end{array}$ & $\begin{array}{l}\text { Станом } \\
\text { на } \\
01.01 . \\
2019 \text { p. }\end{array}$ & $\begin{array}{l}\text { Станом } \\
\text { на 01.01. } \\
2020 \text { p. }\end{array}$ & $\begin{array}{l}\text { Темпи } \\
\text { зроста- } \\
\text { ння (зни- } \\
\text { ження) }\end{array}$ \\
\hline Усього & 1114045 & 1153326 & 103,5 & 58441 & 59018 & 101,0 \\
\hline $\begin{array}{l}\text { Законодавці, вищі } \\
\text { державні службовці, } \\
\text { керівники, менеджери } \\
\text { (управителі) }\end{array}$ & 68689 & 68926 & 100,3 & 3385 & 3296 & 97,4 \\
\hline Професіонали & 97659 & 103365 & 105,8 & 6215 & 7243 & 116,5 \\
\hline Фахівці & 107322 & 115318 & 107,5 & 6208 & 6401 & 103,1 \\
\hline Технічні службовці & 46835 & 51497 & 110,0 & 2161 & 2533 & 117,2 \\
\hline $\begin{array}{l}\text { Працівники сфери торгівлі } \\
\text { та послуг }\end{array}$ & 172561 & 175488 & 101,7 & 8820 & 8547 & 96,9 \\
\hline $\begin{array}{l}\text { Кваліфіковані робітники } \\
\text { сільського та лісового } \\
\text { господарств, } \\
\text { риборозведення та } \\
\text { рибальства }\end{array}$ & 32979 & 33071 & 100,3 & 576 & 631 & 109,5 \\
\hline $\begin{array}{l}\text { Кваліфіковані робітники } 3 \\
\text { інструментом }\end{array}$ & 165635 & 169220 & 102,2 & 13851 & 13584 & 98,1 \\
\hline $\begin{array}{l}\text { Робітники з } \\
\text { обслуговування, } \\
\text { експлуатації та } \\
\text { контролювання за роботою } \\
\text { технологічного } \\
\text { устаткування, складання } \\
\text { устаткування та машин }\end{array}$ & 244087 & 250203 & 102,5 & 9781 & 9548 & 97,6 \\
\hline Найпростіші професії & 178278 & 186238 & 104,5 & 7444 & 7235 & 97,2 \\
\hline
\end{tabular}

Джерело: [4].

За даними Державної служби зайнятості найбільший попит роботодавців на кваліфікованих робітників - це водії, швачки, оператори та машиністи котельної, слюсарі, електромонтери, електрогазозварники, токарі, трактористи, монтери колії, оператори заправочних станцій, робітники 3 комплексного обслуговування будинків, маляри, муляри та столяри.

Затребуваними на ринку праці України є також працівники сфери послуг: продавці, кухарі, пекарі, охоронники, офіціанти, помічники вихователя, молодші медичні сестри, бармени, перукарі, соціальні робітники, кондуктори громадського транспорту, пожежники-рятувальники тощо. Має 
місце високий попит на професіоналів та фахівців 3 досвідом роботи - бухгалтерів, вихователів, вчителів, лікарів, інженерів різних галузей, фармацевтів, провізорів. Серед найпростіших професій найбільш затребувані підсобні робітники, прибиральники, вантажники, двірники, опалювачі, укладальники-пакувальники, комірники, кухонні робітники та сторожі.

Результати спеціальних досліджень, численні публікації з питань ринку праці та зайнятості переконують у тому, що застосування нестандартних форм зайнятості все більше і більше має не добровільний, а вимушений характер. Останне пов'язано 3 дефіцитом гідних робочих місць і відсутністю можливості працювати на умовах стандартного трудового договору (не обмеженого певним періодом і повну норму робочого часу) [2].

В Україні разом з надлишковою пропозицією робочої сили має місце незадоволений попит на вакантні робочі місця. Це зумовлено насамперед невідповідністю між професіями та рівнем кваліфікації працівників, які мають бажання працювати, та вимогами, які до них пред'являються. Дефіцит кваліфікованих кадрів за професіями призводить до зниження продуктивності праці та конкурентоспроможності вітчизняних підприємств, неможливості забезпечення інноваційного розвитку економіки.

В цілому ж за 2019 рік офіційного безробітного населення зменшилося на 39818 осіб порівняно з 2018 роком з 1064244 до 1024426 тис осіб. Станом на 1 січня 2020 року кількість зареєстрованих безробітних в нашій країні становила 338163 осіб, з них 44\% мають вищу освіту, 37\% - професійнотехнічну, 19\% - загальну середню.

На 1 січня 2020 року на одну вакансію в середньому по Україні претендувало 6 безробітних. Найбільше претендентів на одне вільне робоче місце спостерігалося в сільському, лісовому та рибному господарствах (43 особи, що пов'язано з сезонністю робіт), у фінансовій та страховій діяльності - 14 осіб.

За видами економічної діяльності серед безробітних, які мали професійний досвід, 20,7\% раніше працювали у сільському господарстві; $16,2 \%$ - в оптовій та роздрібній торгівлі; $14,9 \%$ - у державному управлінні й соціальному страхуванні; $14,5 \%$ - у переробній промисловості (рис. 1).

За професійними групами, серед зареєстрованих безробітних переважають робітники 3 обслуговування, експлуатації устаткування; працівники сфери торгівлі та послуг; законодавці, вищі державні службовці, керівники; представники найпростіших професій (рис. 2).

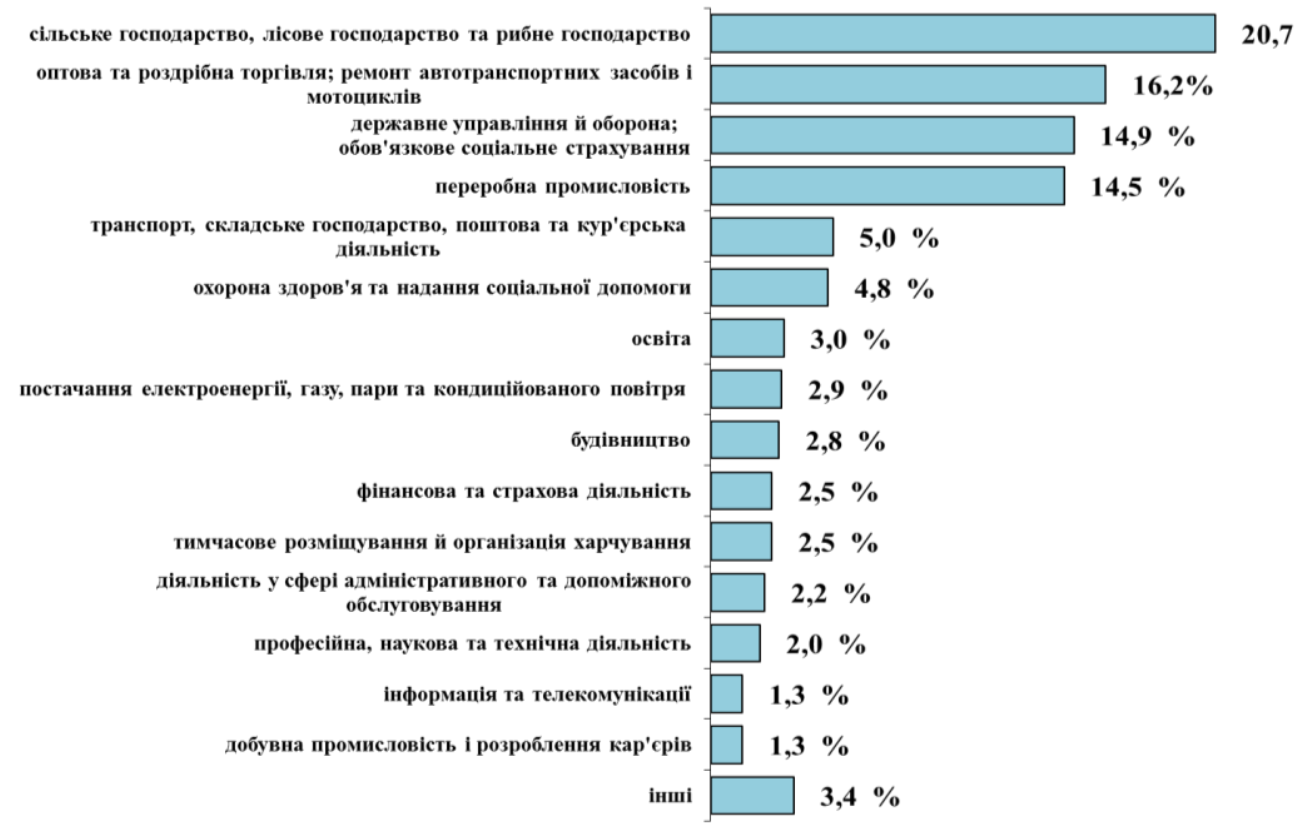

Рис 1. Структура зареєстрованих безробітних за видами економічної діяльності за січеньжовтень 2019 р, \%

Джерело: [4]. 


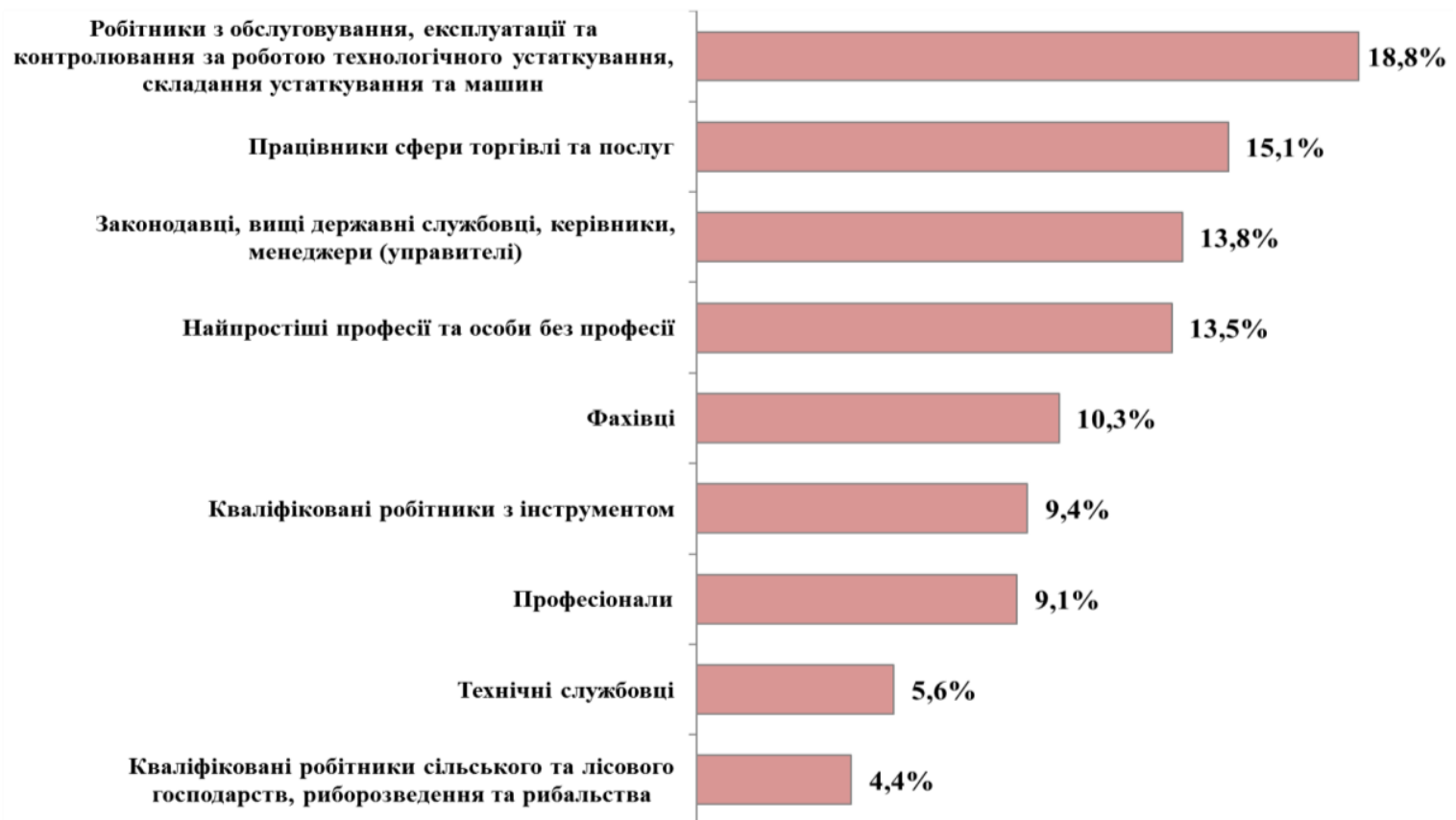
2019, \%

Рис 2. Структура зареєстрованих безробітних за професійними групами на січень-жовтень

Джерело: [4].

Даній ситуації послужив затяжний характер кризи, в якій перебуває українська економіка, що спричинив істотне зменшення обсягів ВВП, а це в свою чергу призвело до значного скорочення кількості робочих місць. Доцільним вважається створення умов для відтворення трудового потенціалу країни, що можливо тільки при досягненні макроекономічної стабілізації, модернізації національної економіки, збереженні існуючих та створенні нових ефективних робочих місць, забезпеченні дієвої державної підтримки конкурентоспроможних вітчизняних виробництв [10, c.379].

Невисока заробітна плата, неможливість утримати сім'ю, забезпечити належне сьогодення та майбутнє своїх дітей змушує одного чи обох батьків виїжджати за кордон з метою отримання більш високооплачуваної роботи. Негативними наслідками зовнішньої трудової міграції $є$, в першу чергу, родинні та соціальні проблеми, які виникають через відсутність повноцінних сімей. Держава, в результаті подібних масових виїздів, втрачає і кваліфіковані кадри, і робочу силу. Оскільки вітчизняний ринок праці конкурує з європейським, де аналогічні посади оплачуються значно вище, то проблема нестачі кваліфікованої робочої сили в Україні може ще більше загостритись.

В іншому випадку відбувається недовикористання та знецінення наявного освітньокваліфікаційного потенціалу на внутрішньому ринку праці, а також до його вимивання за межі України. Виникає феномен «надлишкової освіти», коли працівники 3 високою формальною підготовкою виконують низько кваліфіковані роботи, що свідчить або про низьку якість освіти, або про нераціональне використання праці. Незатребувані на вітчизняному ринку праці фахівці заповнюють вакансії, пропоновані іноземними державами. Як наслідок, Україна стає постачальником людських ресурсів: фізично - некваліфікована (до якої часто залучені кваліфіковані фахівці) чи надкваліфікована (в наукових центрах) праця у країнах Європи та світу. Відбувається вимивання кваліфікованих кадрів, які не можуть реалізуватися на внутрішньому ринку праці (через відсутність попиту й наднизьку вартість праці); економічно - аутсорсінг та аутстафінг, коли працівники України працюють на збільшення ВВП країн Європи та світу [10, с.379 - 380].

Слід відзначити, що після російської збройної агресії проти нашої держави відбулось зменшення трудової міграції українців до Росії та зростання кількості трудових мігрантів до країн-членів Європейського Союзу. Найбільшими реципієнтами української робочої сили $є$ Польща, Італія, Португалія та Іспанія. 
Асиметрії на ринку праці пов'язані передусім з невідповідністю між чисельністю людей, які мають вишу освіту, та обсягами робіт, для виконання яких вона реально потрібна. Тому багатьом працівникам радять «забути все, чому їх вчили в університеті» й здобувати досить примітивні практичні навички, які необхідні для успішного виконання трудових функцій. Це призводить до фіктивізації сформованого в освітній сфері людського капіталу, його різноманітних деформацій, зниження цінності вищої освіти. За умови інноваційного розвитку національної економіки, створення нових робочих місць для висококваліфікованих працівників ця проблема була б менш гострою, адже попит ринку праці дедалі більшою мірою відповідав би зростаючому трудовому потенціалу суспільства. Однак наявна кон'юнктура вітчизняного ринку праці призводить до фіктивізації людського капіталу великої частини працівників 3 вищою освітою, посилення міграційних настроїв та збільшення відпливу висококваліфікованих працівників за кордон [1, с. 24].

Тривала недосконалість взаємодії суб’єктів ринків праці та освіти негативно позначилася на обох ринках, зумовлюючи невідповідність професійно-кваліфікаційних стандартів вимогам національної економіки, погіршуючи якість підготовки кадрів та загострюючи дисбаланс вакансій за професіями. Це призвело до зниження продуктивності праці, існування неповної та неформальної зайнятості, зростання структурного та технологічного безробіття. Окрім того, при вступі в навчальні заклади абітурієнти, в основному, не думають про перспективи працевлаштування за обраною спеціальністю. А тому багатьом випускникам важко знайти роботу через відсутність потрібних вакансій чи низьку оплату праці.

Структурні зміни світової та національної економіки мають вплив на формування сукупного попиту на ринку праці на кваліфікованих кадрів, які володіють високим рівнем інтелектуального потенціалу і зможуть поєднати декілька професій. В умовах конкуренції вища та професійна освіта повинні бути гнучкими і орієнтуватися на перспективні потреби економіки.

Таким чином, метою взаємодії суб’єктів ринків праці та освіти є максимальне задоволення потреб всіх зацікавлених сторін, що з одного боку дозволяє збалансувати попит та пропозицію на кваліфіковану робочу силу, досягти вищої якості освіти (покращення іiі змісту та удосконалення форми), а з іншого - задовольнити всіх стейкхолдерів у відповідних освітніх продуктах та послугах [7, c.72].

В останні роки студенти денної форми навчання поєднують здобуття освіти разом з роботою, тобто працюють неофіційно або з неповною зайнятістю. Така молодь найчастіше орієнтуються на рівень заробітної плати та гнучкий графік роботи, а не на спеціальність. Це негативно впливає на якість отриманих знань та здобутий кваліфікаційний рівень.

Дуже багато молоді України обирає зарубіжні країни для отримання освіти. Серед найбільш бажаних для навчання країн є Польща, Німеччина, Канада, Італія, Чехія, США, Іспанія, Австрія, Франція та Угорщина. Більшість студентів здобуває вищу освіту саме для кращого працевлаштування.

Зростання попиту вітчизняних абітурієнтів на освіту за кордоном викликане переважно бажанням емігрувати в більш розвинені країни на тлі незадоволення перебігом реформ та процвітанням корупції в Україні. На тлі посилення міграційних настроїв зростає конкурентоспроможність освітніх послуг закордонних ВНЗ, навчання у яких розглядається українськими студентами як можливість працевлаштування в зарубіжних країнах, отримання більш конкурентоспроможного диплому на світовому ринку праці [3, с. 40 - 41].

Кампанія CEDOS провела опитування, щоб з'ясувати, чому українські студенти обрали навчання саме в польському університеті. Найбільша кількість студентів обрали такі відповіді: низька вартість життя - 39\% респондентів; можливість навчатися зі знижкою - 29\%; нижчі вимоги для вступу, ніж в інших країнах - 28\%. Студенти також відзначили перспективу знайти хорошу роботу за спеціальністю в Польщі, якість освіти в обраному університеті та якість освіти на обраній навчальній програмі (22\% обрали кожен із цих варіантів). По $12 \%$ обрали перспективи знаходження роботи в Польщі (не обов'язково за спеціальністю), хороші умови життя та прості умови для отримання дозволу на тривале перебування в країні.

В сьогоднішніх умовах ринку праці важливого значення набувають інформація, наука, знання, які стають головними рушійними силами розвитку. А перехід до розбудови інформаційної економіки докорінно змінює роль людини в суспільно-економічній системі, перетворюючи іiі не тільки в 
головний суб'єкт економіки, а й у визначальний критерій та мету розвитку, що тим самим формує інтелектуальний ринок праці [10, с. 380].

Науково-технічний прогрес призводить до масової автоматизації, роботизації, комп'ютеризації, цифровізації і, відповідно, до суттєвих змін у структурі зайнятості, які створюють серйозні виклики для ринків праці та освіти. Варто зазначити, що перед вітчизняними навчальними закладами усіх рівнів акредитації стоять першочергові завдання у підготовці висококваліфікованих спеціалістів, які будуть конкурентоспроможними на ринку праці. Позитивним $€$ те, що в Україні в останні роки запроваджується дуальна форма навчання, яка передбачає поєднання навчання студента в аудиторії та отримання практичних навиків у підприємствах, установах, організаціях, тобто майбутніх робочих місцях.

Вища та професійна освіта в сучасних умовах повинна бути гнучкою і орієнтуватися на перспективні зміни потреб національної економіки. В іншому випадку постійно зростатиме невідповідність між попитом і пропозицією кваліфікованих кадрів. Для подолання освітньокваліфікаційних дисбалансів на ринках освіти і праці потрібно оновити зміст освітніх стандартів та навчальних програм, застосовувати нові методики викладання дисциплін та технології навчання, удосконалити механізм взаємодії обох ринків. Адже перевагу отримуватимуть найбільш креативні працівники, які є носіями унікальних компетенцій, здатними створювати інноваційні технології і рішення.

Радикальні зміни в інституті зайнятості - це об'єктивна відповідь економічної системи та їі соціально-трудового складника на виклики динамічних змін - технологічних, організаційних, мотиваційних, демоекономічних, споживчих тощо. Водночас це є свідченням розвитку відносин постіндустріальної економіки (економіки знань) у функціонуванні сучасного ринку праці. Нова ієрархія факторів економічного розвитку, інтенсивне впровадження нових прогресивних технологій, передусім інформаційно-комунікаційних, дедалі більше зумовлюють як трансформацію форм зайнятості, так і зростання вимог до суб’єктів трудової діяльності. Посилення ролі творчої людини у виробництві сприяє нарощенню попиту на інтелектуальну, креативну працю, на висококваліфікованих працівників зі схильністю до постійного навчання, засвоєння та інтерпретації нового. Людський капітал стає провідним фактором економічного розвитку, найефективнішим економічним ресурсом [8, с. 13].

Комп’ютеризація й Інтернет створили нові сфери праці: розроблення програмного забезпечення, створення веб-сайтів, різноманітні надомні он-лайнові інформаційні та консультаційні послуги (останні зазвичай погано оплачуються). Навіть якщо IT створюють нові види діяльності, вони не гарантують оплачуваних вакансій у кількості, рівній тій, яка була ними знищена [6, с. 66].

Діджиталізація - це глобальна тенденція, яка зачіпає всі галузі економіки. Вона впливає на: створення нових і втрату старих робочих місць; зростання попиту на професії майбутнього; підвищення ризиків безробіття і соціальної напруги; відповідну реакцію системи освіти. Тому державі потрібно реформувати політику зайнятості 3 метою захисту населення від масового звільнення, здійснювати підтримку безробітних внаслідок інноваційного розвитку та цифровізації економіки. Для покращення ситуації на ринку праці держава повинна сприяти створенню нових робочих місць в інноваційних і високотехнологічних секторах економіки, що в кінцевому вплине на підвищення рівня соціально-економічного розвитку країни.

Глобалізаційні процеси, посилення конкуренції, розвиток економіки знань та інформаційних технологій потребують оновлення системи регулювання ринку праці. Найбільш перспективними інструментами $є$ ті, які враховують об'єктивний вплив глобальних трендів і спрямовані на активізацію інноваційної зайнятості, підприємницької активності населення, забезпечення збалансованості ринку освітніх послуг та ринку праці. Регулювання ринку праці є важливим напрямом розвитку національної економіки та об'єктивно необхідним процесом, оскільки безпосередньо впливає на розширення зайнятості, підвищення добробуту та якості життя населення. В процесі регулювання ринку праці держава повинна створити відповідні умови для формування людського капіталу на всіх його стадіях: відтворення, становлення, розвитку, виходу з ринку праці.

Податкова політика нашої держави призводить, на жаль, до функціонування неформальної зайнятості, що впливає на недоотримання доходів державного та місцевого бюджетів, а також на неможливість найманими працівниками отримувати у непередбачених випадках соціальні виплати, 
пенсії в майбутньому. Для дотримання соціальної справедливості та рівних можливостей доступу до робочих місць ринок праці повинен регулюватися державою, яка має створити економічні умови для забезпечення кожного члена суспільства власного добробуту; гідного рівня життя людей, що стали соціально вразливими з об'єктивних причин.

На сьогоднішній день Україна все ще перебуває на етапі нестабільної моделі суспільного устрою та розподілу соціальної відповідальності. Функціонування соціальної політики відбувається у складних соціально-демографічних, економічних, політичних умовах. Попри декларовані соціальні зобов'язання держави, їх обсяг доводиться постійно скорочувати, а відповідальність перерозподіляти на інші рівні - місцевий, корпоративний та дедалі частіше - на рівень індивіду. Погано працюють соціальні ліфти: багато громадян не можуть у повній мірі реалізувати свої професійні знання, знайти гідну роботу. Недостатньо реалізується потенціал людей, які мають менші, ніж інші, здібності або обмежені фізичні можливості працювати, кому важко долучитись до стандартних умов праці та трудових відносин. У суспільстві існує надмірна нерівність у доходах і у доступі до ресурсів та суспільних благ. Певний ступінь диференціації є природнім для зрілої ринкової економіки, проте надмірний розрив сприймається як несправедливість і слугує джерелом соціальної напруженості [12, c. 70].

Регулювання ринку праці здійснюється через пряме державне втручання (державні програми зайнятості, державне замовлення на підготовку кадрів, пільгове оподаткування та кредитування) i опосередковане ринком (коригуючий вплив на структурні пропозиції національної економіки та розподіл робочої сили). Державна політика зайнятості повинна створити умови для підвищення економічної активності населення, забезпечувати ефективну зайнятість та соціальний захист від безробіття.

Позитивним для вітчизняного ринку праці має стати Програма «Доступні кредити 5-7-9\%», презентована Кабінетом міністрів України 3 лютого 2020 року. Вона забезпечить умови для розширення власного мікро- та малого бізнесу під низькі відсотки - 5, 7 або 9\%. В 2020 році Уряд виділив на дану програму 2 млрд грн, якими держава компенсує підприємцям частину кредитного навантаження. Це приблизно 50 тисяч доступних кредитів, 3 допомогою яких буде можливо створити до 90 тисяч нових робочих місць і залучити близько 2 млрд грн внутрішніх інвестицій. Більшу компенсацію відсотка за кредитом отримають ті представники малого бізнесу, які створять більше робочих місць.

Висновки та пропозиції. В умовах глобалізації та розвитку постіндустріальної економіки ринок праці України стикається 3 багатьма сучасними викликами. Без належного рівня соціальноекономічного розвитку нашої країни, вирішення воєнного конфлікту з Росією та оптимального державного регулювання даний ринок не зможе функціонувати ефективно. Таким чином, пріоритетні напрямки реформування українського ринку праці полягають у наступному: тісна взаємодія ринків праці та освіти; підвищення якості та конкурентоспроможності робочої сили; стимулювання створення нових робочих місць; посилення мотивації до легальної зайнятості; сприяння розвитку підприємництва та самостійної зайнятості; вдосконалення системи оплати праці; соціальна підтримка вразливих верств населення. Важливою умовою підвищення ефективності функціонування ринку праці в сучасних умовах повинні бути інновації в усіх галузях та сферах національної економіки. Адже тільки висококваліфікований кадровий потенціал, гнучкий до реалій сьогодення та нових світових викликів, зможе забезпечити економічне процвітання нашої держави.

\section{Джерела та література}

1. Бринцева Е. Г. Человеческий капитал в сфере науки и образования: тенденции фиктивизации. Człowiek - Społeczeństwo - Gospodarka. Tom 5: Problemy zatrudnienia w organizacjach. Uniwersytet Zielonogórski. 2017. Р. $15-26$.

2. Гідна праця: імперативи, українські реалії, механізми забезпечення: монографія / М-во освіти і науки України, ДВНЗ «Київ. нац. екон. ун-т ім. Вадима Гетьмана»; [А. М. Колот, В. М. Данюк, О. О. Герасименко та ін.]; за наук. ред. А. М. Колота. Київ: КНЕУ, 2017. 504 с.

3. Грішнова О. А. Людський, інтелектуальний і соціальний капітал України: сутність, взаємозв’язок, оцінка, напрями розвитку. Соціально-трудові відносини: теорія та практика. 2014. № 1. С. 34 - 42.

4. Державна служба зайнятості. URL: https://www.dcz.gov.ua/ 
5. Державна служба статистики України. URL: www. ukrstat.gov.ua

6. Есть ли будущее у капитализма? Сб. статей И. Валлерстайна, Р. Коллинза, М. Манна, Г. Дерлугьяна, К. Калхуна / пер. с англ. под ред. Г. Дерлугьяна. М.: Издво Ин-та Гайдара, 2015. 320 с.

7. Ільїч Л. М. Взаємодія ринків праці та освіти: сутність, характерні риси та модель функціонування. Економіка та держава. 2017. № 4. С. 69 - 74.

8. Колот А. М., Герасименко О. О. Новітні глобальні тенденції у сфері зайнятості і доходів та їх вплив на соціальну нерівність. Соціально-трудові відносини: теорія та практика. 2018. № 1. С. 6 - 33.

9. Конвенція про основні цілі та норми соціальної політики № $117 . \quad$ URL: https://zakon.rada.gov.ua/go/993_016

10. Косович Б., Дмитрук В. Ринок праці в умовах глобалізації. Львівський національний університет ім. Івана Франка. Серія економічна. 2014. Вип. 51. С. 376 - 383.

11. Людський розвиток в Україні. Інноваційні види зайнятості та перспективи їх розвитку: кол. монографія / за ред. Е. М. Лібанової. Київ: Ін-т демографії та соціал. дослідж. ім. М. В. Птухи НАН України, 2016. 328 c.

12. Людський розвиток в Україні: інституційне підгрунтя соціальної відповідальності: кол. моногр. / за ред. Е. М. Лібанової; Ін-т демографії та соціальних досліджень імені М. В. Птухи НАН України, 2017. 368 с.

\section{References}

1. Bryntseva E. G.(2017) Chelovecheskii kapital vsfere nauki i obrazovaniia: tendentsyi fiktivizatsyi [Human capital in the fields of science and education]. Człowiek - Społeczeństwo - Gospodarka.Problemy zatrudnienia w organizacjach. Uniwersytet Zielonogórski. 5, 15 - 26 [in Russian].

2. A.M. Kolot (Eds), V.M. Danyliuk, O.O. Herasymenko (2017) Hidna pratsia: imperatyvy, ukrainski realii, mekhanizmy zabezpechennia[Decent work: imperatives, Ukrainian realitiy, mechanisms of providing]. Ministerstvo osvity i nauky Ukrainy, DVNZ «Kyiv. nats.ekon. un-t im. Vadyma Hetmana».504, Kyiv: KNEU [in Ukrainian].

3. Hrishnova O.A. (2014) Liudskyi, intelektualnyi i sotsialnyi kapital Ukrainy: sutnist, vzaiemozviazok, otsinka, napriamy rozvytku [Human, intellectual and social capital in Ukraine: essence, interconnection, evaluation, directions of development]. Sotsialno-trudovi vidnosyny: teoriia ta praktyka.1,(pp.34 - 42) [in Ukrainian].

4. Derzhavna sluzhba zainiatosti[State employment service].Retrieved from https://www.dcz.gov.ua/ [in Ukrainian].

5. Derzhavna sluzhba statystyky Ukrainy [State statistes service of Ukraine]. Retrieved from https://www.ukrstat.gov.ua [in Ukrainian].

6. I. Vallerstaina, R. Kollinza, M. Manna, G. Derlugiana, K. Kalkhuna (2015) Iest li budushchee u kapitalizma? [Does the capitalism have the future?].(G. Derlugiana (Ed), M.: Izdvo In-ta Gaidara, (Trans.) [in Russian].

7. Ilich L.M. (2017) Vzaiemodiia rynkiv pratsi ta osvity: sutnist, kharakterni rysy ta model funktsionuvannia [Interaction between labour and educational markets: essence, characteristic features and the model of functioning]. 4, (pp.69 - 74) Ekonomika ta derzhava-Economy and the state. [in Ukrainian].

8. Kolot A.M., Herasymenko O.O. (2018) Novitni hlobalni tendentsii u sferi zayniatosti i dokhodiv ta yikh vplyv na sotsialnu nerivnist [Modern global tendencies in the sphere of employment and income and their influence on social inequality]. Sotsialno-trudovi vidnosyny: teoriia ta praktyka-Sociallabourrelations:theoryandpractice.1,pp.6 33 [in Ukrainian].

9. Konventsiia pro osnovni tsili ta normy sotsialnoi polityky № 117 [Convention on main goals and norms of social politics № 117]. Retrieved from https://zakon.rada.gov.ua/go/993_016

10. Kosovych B., Dmytruk V. (2014) Rynok pratsi v umovakh hlobalizatsii [Labour market in the context of globalization].Collected papers (51), (pp.376-383) Lviv National UniversityIvan Franko.[in Ukrainian].

11. Libanova E.M. (Red.) (2016) Liudskyi rozvytok v Ukraini. Innovatsiyni vydy zayniatosti ta perspektyvy yikh rozvytku: kol.monografiia [Human development in Ukraine. Innovational types of employment and the prospects of their development: collective monograph]Institute of Demography and Social. research. them. M. V. Ptukhy of NAS of Ukraine.Kiev:[in Ukrainian].

12. Libanova E.M. (Red.) (2017) Liudskyi rozvytok v Ukraini: instytutsiyne pidgruntia sotsialnoi vidpovidalnosti: kol. monografiia [Human development in Ukraine: institutional basis for social responsibility: collective monograph]Institute of Demography and Social. research. them. M. V. Ptukhy of NAS of Ukraine. Kiev: [in Ukrainian].

Стаття надійшла до редакції 20.02.2020 р. 